Evelyn Wareham

\title{
'Was war, ist Rauch': Expressions of Exodus in the Poetry of Paul Celan and Karl Wolfskehl
}

\begin{abstract}
Denn das Gedicht ist nicht zeitlos. Gewiß, es erhebt einen Unend lichkeitsanspruch, es sucht durch die Zeit hindurchzugreifen - durch sie hindurch, nicht über sie hinweg. 1
\end{abstract}

The poems of Paul Celan and Karl Wolfskehl may seem at first glance to be poles apart, but they can be linked in both subject and approach to language. Both wrote poetry that addressed their contemporary situation, that sought to draw attention to the condition of their society and the fate of their culture. Wolfskehl and Celan were, however, writing within different historical contexts, with divergent backgrounds; their poetry must be understood within these parameters. Neither poet's works were 'zeitlos'.

There are few studies which compare the works of Paul Celan and Karl Wolfskehl, and none do so at great length. In general, Wolfskehl is placed within the George-Kreis, and compared with poets writing before World War II, while Celan scholarship focuses on his relationship to various post-war poets and philosophical movements. Celan knew Wolfskehl's 1913 essay on Judaism, and probably also his poetic works. 2 Both Wolfskehl's Gesammelte Werke and his Briefe aus dem Exil were published during the period in which Celan was working on Die Niemandsrose - a time in which Jewish themes were increasingly pronounced in Celan's poetry. It was also in 1960 that Celan visited the Federal Republic to receive the Georg-Büchner prize in Wolfskehl's home city, Darmstadt. However, Celan's poetry reveals little evidence of any direct influence from the older poet.

Existing studies of Celan and Wolfskehl thus focus on a textual comparison. Klaus Weissenberger contrasts Celan and Wolfskehl to illustrate his thesis on the development of language in exile poetry. $3 \mathrm{He}$ regards Wolfskehl as an author in whom the crisis of

1 Paul Celan, "Ansprache anläßlich des Literaturpreises der freien Hansestadt Bremen", in: Gesammelte Werke, Frankfurt a. M. 1983, III, p. 186.

2 Cindy Mackey, Dichter der Bezogenheit: A Study of Paul Celan's Poetry with Special Reference to Die Niemandsrose, Stuttgart 1997, p. 317

3 Klaus Weissenberger, "Poetic Rhythm and the Exile Situation", in: Protest - 
exile brought on a "formal adjustment" in "poetic rhythm", while Celan's abandonment of traditional metres, disintegrating syntax and word formation serve as an example of a "complete break" with the past. Paul Hoffmann also compares the two in the context of poetic development. 4 Hoffmann notes that while the poetic styles of Celan and Wolfskehl are diametrically opposed, the two poets are bound in ethos. He argues that the inescapable burden of the historical situation unites Wolfskehl's works with those of post-war German poets such as Celan. In his words:

Die letzte Entwicklungsstufe Wolfskehlscher Dichtung antizipiert wesentliche Momente der Entwicklung der deutschen Lyrik nach der Katastrophe [...] gleich Wolfskehl bleiben [die jüngeren Dichter] durch eine geschichtliche Situation gezeichnet, die ihnen ein Wissen aufbürdet, $[\ldots]$ vor dessen grauenvollem Inhalt die Sprache versagt und Lyrik ihre Berechtigung zu verlieren droht.

In addition, he argues, Celan and Wolfskehl share a background of Jewish "Sprachmystik" and a repulsion at language used by a cataclysmic reality. As Hoffmann argues, "Das Trauma der Dichter ist die geschändete Sprache" - the two poets share their experience of the pain of a language stained by misuse, silenced by its own helplessness. Both pronounce the death of the word.5

In this paper I intend to test this argument that the poems of Celan and Wolfskehl are connected through their Jewish background and their reflection of the historical situation with an analysis of Wolfskehl's Hiob oder die Vier Spiegel and Celan's Die Niemandsrose. These volumes exemplify both authors' reactions to their situation on the periphery, as Jews and Germans, as poets and survivors. Both are often described as the works in which the authors are most concerned with exploring their personal relationships to Judaism.

Exile - Tradition: Essays on German Exile Literature, ed. J. P. Strelka, R. F Bell \& E. Dobson, University Alabama 1979, pp. 133-144.

4 Paul Hoffmann, "Wolfskehls Dichtung im Entwicklungszusammenhang der modernen Lyrik", in: Karl Wolfskehl Kolloquium: Vorträge - Berichte - Dokumente, ed. P. G. Klussman, J. U. Fechner \& K. Kluckner, Amsterdam 1983, pp. 61-85.

5 Ibid., pp. 76-78. Klaus Voswinckel also notes the similarity of Wolfskehl's exclamation of the death of the word and Celan's phrase 'Ein Wort - du weißt: eine Leiche.' [Karl Wolfskehl, Gesammelte Werke, Claasen, 1960, I, p. 177; Celan, GW, I, p. 125], Klaus Voswinckel, Paul Celan: Verweigerte Poetisierung der Welt: Versuch einer Deutung, Heidelberg 1974, p. 109. 
Cindy Mackey describes Die Niemandsrose as a work in which "Celan was [...] attempting, more explicitly than ever before, to come to terms with his Jewishness and its conflict with [...] his German cultural heritage".6 Although the themes of Jewishness and loss occur in earlier works, it is Die Niemandsrose, written from 1959 to 1962 , some fifteen years after the Holocaust, which most reflects a context in which Celan was reassessing his relationship to his own past and his lost homeland, the Bukovina.7 Through the 1950s his interest in Kabbalism had increased, as had his interest in translating Russian Jewish writing. The volume is dedicated to the memory of Ossip Mandelstamm, who was killed in a Soviet concentration camp in 1939. In 1960 Celan renewed contact with an old friend now living in Moscow, Erich Einhorn, who reminded him of his life in the Bukovina and brought him into contact with Mandelstamm's widow.8 This was a period in which the Holocaust underwent a revival in the public mind due to the Eichmann trial in Jerusalem from 1960 to 1961 and the Auschwitz trial in Frankfurt from 1961 to 1963.9 Celan was concerned with what he saw as rising anti-Semitism in Germany, and although this period was that in which his work was most publicly rewarded, he increasingly felt that it was misunderstood and that critics were against him. In 1964 he wrote to another old friend from the Bukovina, Edith Silbermann:

ich habe seit 1947, also seit dem Jahr indem ich Bukarest verlassen habe, viele Dinge angesammelt - manchmal, insbesondere seit drei Jahren, habe ich Mühe, damit fertig zu werden. Ich bin, mit anderen Worten, alles andere als ein begeisterter Anhänger der westlichen Welt, und daß ich die Dinge in Deutschland mit - um es nur so zu nennen - Skepsis verfolge, weißt Du ja bereits [...] Mein Enthusiasmus - der groß war - ist dahin.10

Celan remained, through-out his life, a "reclusive outsider", haun-

6 Mackey, Dichter der Bezogenheit, p. 117.

7 Although the term 'Holocaust' is the subject of some debate, in relation to Celan it seems more appropriate than 'Shoah' which is most often used to refer specifically to the Jewish genocide rather than to the full catastrophe.

8 Marina Dmitrieva-Einhorn, "Wo ich mit meinen Gedanken bin", in: Die Zeit, 44, 27 October 1995, p. 63.

9 Cf. Sidra EdKoven Ezrahi, By Words Alone: The Holocaust in Literature, Chicago 1980.

10 Celan to Edith Silbermann, 5 March 1964, quoted in Edith Silbermann, "Erinnerungen an Paul Celan-Antschel", in: A. D. Colin, Argumentum e Silencio: International Paul Celan Symposium, Berlin and New York 1989, p. 442. 
ted by his memories of the past.11

Unlike Celan, Wolfskehl was a mature author when his world was shattered by the Nazi rise to power. With exile, especially in New Zealand, he was transformed from an intellectual and literary socialite, the "Zeus of Schwabing", into a lonely outsider living at what he saw as the geographic and cultural periphery of the earth.12 In Wolfskehl's writings of the 1930s and 1940s the focus was on his personal suffering and that of his circle of friends, who were divided into those scattered around the globe and those who remained in fascist Europe with whom he was unable to communicate after 1939.

In Hiob oder die vier Spiegel Wolfskehl linked his situation to the experience of suffering and diaspora in Jewish history. Although Wolfskehl's Die Stimme spricht, published in 1934, had dealt exclusively with Jewish themes, it was this later work in which his exploration of Jewish identity took place most personally and most explicitly in the context of his contemporary situation. Regarding the reworking of his Jewish, German and Roman heritage in Die drei Welten und das Lebenslied, Wolfskehl declared that "Von all den bildenden Welten blieb mir nur noch diese Gemeinschaft, diese Ahnschaft, diese zeitlose Idee".13 In exile from Europe due to his 'racial' identity Wolfskehl found that it was his status as Jew which endured, and Job's suffering with which he most identified. As Margot Ruben writes: "Mit der Abwendung von Europa [sah sich] Wolfskehl fortan im Bild des Hiob, des geschlagenen und auserwählten Hiob".14

The theme of being on the periphery, of exile, recurs through-out the Hiob-cycle. In "Hiob Israel", the first stanza labels the Jew an eternal outsider: "Selbst immer Kante, Rand und Saum und Küste". 15 "Hiob Simson", Job the disempowered, captive Jewish hero, laments his position as "letzter Stamm am Rand".16 The central theme of Wolfskehl's Hiob-cycle is suffering and its meaning for Jewish history and belief. The "Vorspruch" begins

11 Michael Winkler, "Paul Celan", in: Major Figures of Modern Austrian Literature, ed. D.G. Daviau, Riverside, California 1988, p. 150.

12 Cf. Peter Berglar, Karl Wolfskehl: Symbolgestalt der deutsch-jüdischen Tragödie, Darmstadt 1969, pp. 13-31.

13 Wolfskehl to Gertrud Gräfin Helmstatt, 1 November 1946, in: BaN I, p. 301.

14 Margot Ruben, 'Einleitung', to BaN I, p. 18.

15 Wolfskehl, GW, I, p. 203.

.16 Wolfskehl, GW, I, p. 206. 
with the words:

\author{
Tränen sind der Seele herber Wein \\ Fliessend aus des Leids uralter Trotte. \\ Lauter dann, von Erdentrübe rein, \\ Glänzt der Wein, heissts, Spiegel Unserm Gotte. 17
}

Without suffering one can not truly know God. The height of Jewish suffering is reached with Hiob Nabi's vision of a future in which the natural world is devastated by a disaster that perverts each of the elements:

\title{
Weh! Alle Wasser verbracken. \\ Weh! Alle Feuer verschlacken. \\ Weh! Alle Luft ist Getös. \\ Alles was gut war, bös. 18
}

The environmental catastrophe destroying water, fire and air is only overridden by the destruction of humankind: "Weh, ER backt euch zu Stein". It is God to whom the catastrophe is attributed: God is identified as the source of pain, which he inflicts to test his chosen people, as he tested Job.

Wolfskehl posits the Jew's neglect of his covenant with God as the grounds for his suffering. In "Hiob Israel" the central role of "das Buch" is emphasised through a poetic structure which repeatedly places it at the end of line or stanza, and often organises rhymes around it. After the fall of the temple, Hiob Israel is identified as the wandering Jew, "suchend noch nach dem Fund" who allows the true Word to be forgotten among many truths. However, with the fourth mirror, "Hiob Maschiach", Wolfskehl ends the cycle on a note of hope. The poetic ' $\mathrm{Du}$ ' is confirmed in his identity, his heritage and beliefs:

Wohl, du kommst zu Dir.

Wohl, du wirst Du.

Aufgang rundum, alles Ein Ja-Hallelu.

Sphären schmelzen in Baruch Hu.

Himmel, Erden Ein Einig Schemah.19

The concluding lines of the poem assert that the time of the

17 Wolfskehl, GW, I, p. 203.

18 Wolfskehl, GW, p. 208.

19 Wolfskehl, GW, p. 215. 
messiah is that which surrounds him and us, that God continues to dwell in the Jewish people.

Like the Hiob cycle the poems of Die Niemandsrose deal with biblical themes, but Celan's primary reaction to this material is fundamentally opposed to that of Wolfskehl. Rather than re-discovering hope and meaning in his status as one of God's chosen people, Celan reacts to Jewish traditions and beliefs with doubt and disbelief. In writing with knowledge of the full extent of the catastrophe, Celan cannot attribute the pain and suffering of the Holocaust to a vengeful and punitive Jewish God - such an interpretation has become untenable if not blasphemous. Nor can he draw any positive lesson from the Holocaust, any vision of salvation through Jewish identity.

Die Niemandsrose follows a thematic path "von der Erschaffung zur Erlösung" 20 but it is written in such a way that it could be interpreted as a form of 'anti-Bible'. Instead of asserting a firm relationship with God, these poems struggle with His absence.21 The assertion of the opening poem, "Es war Erde in Ihnen" is that no meaning can be discovered in the suffering of the Holocaust, the only possible reaction is 'Verstummen', the rejection of language. The poem recalls the form of the "Todesfuge" but self-consciously without its use of what critics had slandered as 'beautifying' metaphor:22

Sie gruben und gruben, so ging ihr Tag dahin, ihre Nacht. Und sie lobten nicht Gott, der, so hörten sie, alles dies wollte, der, so hörten sie, alles dies wusste.

Sie gruben und hörten nichts mehr;

sie wurden nicht weise, erfanden kein Lied erdachten sich keinerlei Sprache.

Sie gruben. 23

While Wolfskehl found wisdom, a song, a language in his experience of exile, in the wake of the Holocaust Celan found the only sane reaction was to remain mute.

Rather than Wolfskehl's lonely, suffering outsider, it is the

20 Cf. Marlies Janz, Vom Engagement absoluter Poesie: Zur Lyrik und Ästhetik

Paul Celans, Frankfurt a. M. 1976, p. 129.

21 Cf. Mackey, Dichter der Bezogenheit, p. 128.

22 Cf. Mackey, Dichter der Bezogenheit, pp. 120-121.

23 Celan, GW, I, p. 211. 
undistinguished mass of the dead who recur as Jewish figures in Celan's Die Niemandsrose - "Alle die Namen, alle die mit/verbrannten Namen".24 While Wolfskehl's poems explore what it is to be Jewish in terms of "die Ahnschaft, die Zeitlose Idee", Celan's works find Jewish identity in the unearthly remains of his people:

In der Luft, da bleibt deine Wurzel, da, in der Luft. 25

The smoke of extermination camp chimneys is that which symbolises his German-Jewish heritage.

"Psalm", perhaps Celan's most acclaimed poem other than "Todesfuge", identifies the Jewish dead, and implicitly also the Jewish living, as the "Niemandsrose" of the volume's title. The poem begins as an 'anti-Psalm' with the statement that 'No one' will again create us from earth and lime, no-one will animate our dust. Yet the second and third stanzas reverse the readers expectations by becoming a 'song of praise' for the No one, the absent God, of the first stanza:

Gelobt seist du, Niemand.

Dir zulieb wollen

wir blühn.

Dir

entgegen.

Ein Nichts

waren wir, sind wir, werden

wir bleiben, blühend:

die Nichts-, die

Niemandsrose 26

The extent to which this negativity should be read as an acceptance of Jewish mysticism has been much debated by critics.27 As Gerschom Scholem writes, the 'Nichts' is one definition of the Jewish God:

24 Celan, GW, I, p. 227.

25 Celan, "In der Luft", GW, I, p. 190.

26 Celan, $G W$, I, p. 225.

27 For an overview of this debate see Mackey, Dichter der Bezogenheit, pp. 128-136. 
da, wo sich die Seele alles Begrenztsein ganz von sich abstreift und, um mit den Worten der Mystiker zu sprechen, in die "Tiefe des Nichts" hinabsteigt, da gerade begegnet sie Gott [...] Das Nichts ist, mit anderen Worten, die Gottheit selbst in ihrem verborgensten Aspekt.28

If the 'Nichts' and the 'Niemand' can be read as a manifestation of God, the poem embodies the type of optimism found in 'Hiob Maschiach' - the blooming rose of Israel is a symbol of hope. But "Psalm" encompasses a rejection of God, an ironic play on the traditions of worship, and also this possible positive reading. Like "Zürich, zum Storchen" with its final words: "Wir / wissen ja nicht, weißt du, / wir / wissen ja nicht, / was / gilt", "Psalm" remains ambivalent in its discussion of God.29

While a strong connection can thus be drawn between some of the themes of Celan's and Wolfskehl's poetry, their poetic structure and language are less easily reconciled. Is it appropriate to compare two styles which seem, on the surface, to have so little in common? Although Celan's style certainly seems to be diametrically opposed to that of Wolfskehl, in fact in some ways the two can be linked. Both Wolfskehl and Celan were linguists who produced translations as well as poetry. Both utilised language in their poetry which is rich in word symbolism, and thus difficult for the casual reader to access. Both reacted to the cataclysm of persecution and mass murder by altering their poetic language and structure.

As a rule, Celan's reaction to suffering and the German-Jewish fate is expressed most clearly in his poetry through his struggle tôwards "Depoetisierung" and "reduction" - through the disintegration of syntax, formation of neologisms, and avoidance of musicality. The poems of Die Niemandsrose are uncharacteristically accessible, melodic and emotional when compared to those which immediately precede and follow them.30 Significantly, this is the volume in which he most often included the personal pronouns "Ich" and "Du" and the last volume in which he consistently utilised rhyme.31 Although his earliest poetry, which is most directly influenced by French symbolism and surrealism, is closest in form to

28 Gerschom Scholem, Die jüdische Mystik, Frankfurt a.M. 1967, p. 27, quoted by Georg-Michael Schulz, Negativität in der Dichtung Paul Celans, Tübingen 1977, pp. 103-107.

29 Celan, GW, I, pp. 214-215.

30 Mackey, Dichter der Bezogenheit, pp. 114-117.

31 Cf. Mackey, Dichter der Bezogenheit, p. 115. 
that of Wolfskehl, of his mature works, this volume is that which still recalls some of Wolfskehl's techniques. While it is not as sensuously rich in repetition, rhyme and structure, it is more musical than Celan's other mature works.

In vivid contrast, Wolfskehl's Hiob oder die vier Spiegel is characterised by its emotional intensity. Wolfskehl constructed tension in his rich texture of sensual and historical vocabulary through carefully created climactic peaks, which he rendered still more emotive by incorporating dynamic breaks in the rhythm, rhyme and syntax. The cycle progresses from the fairly measured, regular style of the "Vorspruch" and "Hiob Israel" to the disintegration of syntax and rhythm in a chant-like frenzy in the final lines of "Hiob Maschiach". Whereas Wolfskehl reacts to his exile through heightened emotion, which Hoffmann describes as "ausgeladender Pathos", the emotional content of Celan's poetry lies beneath its surface.32 By continuing to write in German, Celan addressed his historical situation. By seeking a 'greyer' language, without musicality, rhyme or a conventionally 'poetic' vocabulary, Celan reacted against the over-dramatised rhetoric of the Nazis as well as against the poetic styles of the past.

The works of Celan and Wolfskehl can thus be linked in a number of respects, however, they remain fundamentally divided from one another. Both Celan and Wolfskehl expressed their reactions to their historical situation by recalling the history of the Jewish diaspora - the tradition of exodus. Both Celan and Wolfskehl composed in a form of language which they sought to make appropriate to their historical situation. But these forms differed radically from one another, perhaps more in proportion to the fifty years difference in age than to the twenty years which divide their works. Despite the apparent similarities in their use of Jewish themes, the two poets projected diametrically opposed interpretations of what it is to be Jewish, and of how that should be expressed in poetry. While Wolfskehl's reaction to his exile could be read as the creation of a song of suffering, that of the younger poet, writing in full knowledge of the scope of the cataclysm, was horrified silence.

32 Hoffmann, "Wolfskehls Dichtung", p. 77. 